\title{
Social Insurance for Religious and Clergy in Polish Legislation
}

This article considers issues pertaining to social insurance for clergy and religious in Poland. More specifically, this article discusses regulations concerning when clergy and religious must enroll in mandatory and/or voluntary retirement, disability, and accident insurance as well as the consequences of not paying the premium when and in the amount it is due. This study also presents the consequences of having more than one insurance title. In practice, these issues raise the most doubts.

Key words: religious, clergy, social insurance, insurance premium.

\section{Introduction}

The Act regarding social insurance systems implemented on October $13,1998^{1}$ differentiated four types of insurance due to the type of risk it protects: retirement and pension insurance, medical and maternity insurance, as well as accident insurance (for work accidents and occupational disease). The clergy are included among those individuals who either must have or be voluntarily covered by these insurances. According to Article 8, section 13 of the u.s.u.s., clergy are defined as priests and members of male and female religious orders within the Catholic Church as well as other church and religious associations, with the exception of seminarians, novices, postulants, and junior candidates who are under 25 years of age. It follows from the above provision that every person who is part of the clergy or a male or

Dz. U. z 2017 r., poz. 1778. Abbreviated hereafter as "u.s.u.s." 
female member of a religious order must be covered by social insurance after being ordained or making final vows regardless of their age and the church to which they belong. This is not the case, however, for seminarians and candidates for religious or monastic life (novices, postulants, etc.) who, according to the statutory provisions, must be enrolled in a social insurance policy after the age of 25. Until then, seminarians, novices, postulants, and junior candidates are excluded from social insurance. They are able, however, to join optional retirement and disability pension plans (Article 7 of the u.s.u.s.). By virtue of the law, these insurances terminate on the day that these individuals have reached the appropriate age, been ordained, or made final vows.

The citizenship of clerics, religious, and candidates for the clerical life does not matter. Consequently, the precepts contained the Act concern both clergy who are Polish citizens and clergy who are citizens of other countries and also take into account the exemptions provided for in Article 5, section 2 of the u.s.u.s, which particularly concerns citizens of foreign countries who are staying in Poland temporarily. Foreigners are considered those who live in countries outside of the European Union, the European Economic Area, and Switzerland. The subjection of those who are from Switzerland to the Polish insurance system is regulated by the Regulation of the European Parliament and of the Council (WE) nr 883/2004 on coordinating social security systems, which was enforced on April 29, 2004. ${ }^{2}$

\section{Mandatory and Optional Insurance for Clergy}

According to Article 6, paragraph 1, point 10 of the u.s.u.s., clergy must have retirement and pension insurance. ${ }^{3}$ An exception to this is contained in Article 9 of the u.s.u.s., which concerns multiple insurance titles. When spiritual ministry is linked to other kinds of professional activity or the collection of certain benefits, then the obligation to be insured is associated with a different legal status than the clerical status, or it includes more titles. In this regard, a number of doubts arise in practice. Employees and members of agricultural production cooperatives and agricultural cooperative groups ${ }^{4}$ who

Dz. Urz. UE L 166 z 30.04.2004 r., str. 1, z późn. zm.

3 This also applies when an individual simultaneously collects unemployment benefits, integration benefits, scholarships during internships, or the vocational training of adults. See Article 9, paragraph 6a of the u.s.u.s

4 For those who have privileged titles, they can collect training, social benefits, and social allowance or remuneration due while coal mining service is provided or when using a scholarship for retraining. 
are also members of the clergy must always have retirement and disability insurance both as farmers whose titles are absolute and also as clergy, provided that they submit the proper application to the Zakład Ubezpieczeń Społecznych [Social Security Administration] (hereafter abbreviated as ZUS; see Article 9, paragraph 1 of the u.s.u.s.). Article 9, paragraph 1 of the u.s.u.s. contains an exception, which concerns the basis for assessing an obligatory retirement insurance contribution. This provision stipulates that, if the amount per month is lower than the minimum wage, then the person who remains in an employment relationship or membership in a farming or agricultural cooperative ex lege must have mandatory retirement and disability insurance, both under absolute titles as well as a cleric or religious. This is also the case when someone who has the status of a cleric is also part of a civil legal agreement (see Article 9, paragraph $2 \mathrm{c}$ of the u.s.u.s.). If clerics obtain profits from a contract for the provision of services in an amount lower than the minimum remuneration, then it is obligatory for them to have insurance.

The mandatory subject of retirement and disability insurance for two titles also includes pastoral ministry and maternity or child benefit allowance (Article 9, paragraph 1d of the u.s.u.s.) as well as the members of a supervisory board for remuneration (Article 9, paragraph 9 of the u.s.u.s.).

Article 9, paragraph 2 of the u.s.u.s. states that a person who meets the conditions for mandatory retirement and disability pension coverage under several titles (remote work contract, an agency agreement, a commission contract, non-agricultural activity, or receiving a salary as a deputy, senator, or clergy) is mandatorily covered by whichever insurance the individual enrolled in first. It follows from this provision that, as a general rule, mandatory social insurance is associated with the earliest insurance title. Consequently, clergy who are contracted to provide services before becoming clergy are excluded from pension and disability insurance. The party of interest may, however, apply for insurance for the remaining, all, or selected titles, or change the insurance title. In this regard, clergy can take advantage not only of insurance titles on a voluntary basis, but also on a compulsory one,${ }^{5}$ which means that, with permission, they can be insured under

$5 \quad$ Similarly, A. Pędzierski, Podstawa wymiaru składek na ubezpieczenia społeczne i ubezpieczenia zdrowotne, P i ZS 1999, no. 9, pg. 33; A. Pędzierski, Zmiany przepisów z zakresu podlegania ubezpieczeniom społecznym $i$ składek na ubezpieczenie społeczne oraz na Fundusz Pracy i Fundusz Gwarantowanych Świadczeń Pracowniczych, P i ZS 2000, no. 1, pg. 16. T. Bińczycka-Majewska is of a different opinion; she thinks that the interested individual may use the 
a different title than the one that was arranged earliest. This does not apply to situations, however, where a member of the clergy runs a non-agricultural business at the same time. In this case, pursuant to Article 9 , paragraph 7 of the u.s.u.s., a given person is mandatorily subject to social insurance as an economic entity regardless of the date the insurance began. In this case, a person cannot exercise the right to change the insurance title.

The right to enroll in voluntary insurance as a member of the clergy can be exercised by someone who receives a retirement or disability pension that combines such benefits with the employment relationship (membership in a cooperative) or civil law contracts. The decree issued by the Appelate Court of Gdansk on June 17, $2015^{6}$ upholds that, once a member of the clergy's right to a retirement pension is acquired, this individual is obligated to pay contributions to the pension and disability insurance pursuant to Article 6, paragraph 1, point 10 of the u.s.u.s. A member of the clergy who receives a pension at the same time as he performs work on the basis of an employment relationship pursuant to Article 9, paragraph 4 of the u.s.u.s. is mandatorily subject to this insurance only as an employee.

The case mentioned above also applies to a member of the clergy who is simultaneously in a service relationship (Article 9, paragraph 8 of the u.s.u.s.). Based on Article 8, paragraph 15 of the u.s.u.s., those in service are professional soldiers and uniformed offices, in particular the Police, Internal Security Agency, and Foreign Intelligence Agency, Border Patrol, State Fire Service, and Customs and Tax Service. Professional soldiers and officers of these services do not fall within the scope of social insurance, but rather social provision. These resolutions, however, raise some doubts. In the first sentence of Article 7 of the Act of February 18, 1994, which speaks about retirement provision for officers of the Police, Internal Security Agency, Intelligence Agency, Military Counterintelligence Service, Military Intelligence Service, Central Anticorrpution Bureau, Border Patrol, Government Protection Bureau, State Fire Service, Customs Service, the Tax Office, and the Prison Service and their families, ${ }^{7}$ it states that, the right to a retirement or disability pension provided for in the Act, along with

option provided for in the said provision only in the case that the person has optional insurance. See T. Bińczycka-Majewska, Zbieg tytutów ubezpieczenia emerytalnego $i$ rentowego $w$ nowym systemie ubezpieczeń społecznych, $\mathrm{P}$ i ZS 2000 , no. 12 , pg. 5 .

Dz.U. z 2016 r., poz. 708 z późn. zm. Abbreviated hereafter as u.z.e.f. 
the right to a retirement or disability pension or to the retirement or family salary provided for in separate regulations, pays out either the higher benefit or the one that the entitled person selects insofar as specific provisions do not state otherwise. The same regulations apply to the Act of December 17, 1998 regarding retirement and disability pensions from the Social Insurance Fund. ${ }^{8}$ Article 95, paragraph 1 of the u.e.r. provides that, in the event that an individual has the the right to several benefits provided for in the Act pays, then he pays for either the higher benefit or the benefit of his choice. This provision also applies in the event that an individual forgoes the right to a retirement or disability pension specified in the Act, along with the right to the benefits provided for in the retirement provision for persons referred to in Article 2, paragraph 2, except when a military or police pension has been calculated in accordance with the precepts set out in Article 15a or Article 18e of the Act issued on December 10,1993, which concerns the retirement provision of professional soldiers and their families, or in Article 15a, Article 15d, or Article 18e of the u.z.e.f. It follows from the aforementioned provisions that a person who acquires a pension under both social provision and social insurance is entitled to only one benefit-namely, the more favorable benefit in terms of the amount, or the one that the beneficiary chooses. The exception to this case is contained in the second sentence of Article 95, paragraph 1 of the u.e.r., which specifies the situations in which this limitation does not apply. As a result, officers of uniformed services who are entitled to retirement on the basis of the regulations indicated have the right to combine benefits from two areas of social security (provision and insurance). This option is also available to professional soldiers and officers who were first called to serve after December 31, 2012. In the case of the latter, this option was also created for individuals enlisted in service after January 1, 1999 and for Customs Service Officers who began serving after September 14, 1999. ${ }^{9}$

Article 2, paragraph 2 of the u.e.r., also points out that professional soldiers and officers of other uniformed services acquire retirement or pension benefits according to the regulations set forth in this Act if they do not meet the conditions necessary to acquire the right (or have lost the right) to benefits specified in the rules on retirement provision for these persons, and to the members of the families who remain after these persons. Submitting additional pension and disability insurance

Dz. U. z 2017 r., poz. 1383 z późn. zm. Abbreviated hereafter as u.e.r.

9 This also concerns customs officers whose employment relationship has changed into a business relationship. 
during service may provide higher-rank officers with better social security benefits. However, considering information about the financial state of the Social Insurance Fund and predictions regarding future pensions, it is unlikely that those in uniform, including those who are simultaneously religious and clergy, would be interested in joining social insurance.

According to Article 11, paragraph 2 of the u.s.u.s., clergy have the right to sign-up for medical insurance if they are covered by mandatory retirement and pension insurance. A contrario clergy who, based on Article 9 of the u.s.u.s., are not subject to retirement and pension insurance at all or who are voluntarily covered by such insurance are not allowed to sign-up for medical insurance. ${ }^{10}$

If clergy have either mandatory or optional retirement and disability insurance, then they are also obliged to enroll in accident insurance (see Article 12 of the u.s.u.s.).

\section{Social Insurance Coverage}

According to Article 13, point 10 of the u.s.u.s., clerics are subject to clerical status and to mandatory insurance (retirement, disability, and accident insurance) from the day that they are admitted to the clerical state. Therefore, from a legal point of view, they are obliged to have insurance starting on the day that they are ordained or make vows. In the case of seminarians, novices, postulants, and junior candidates, they are obliged to have insurance starting when they have reached 25 years of age. The insurance expires the moment that these individuals resign from or leave the religious or clerical state before the age indicated. In the Decree of August 21, 2013, ${ }^{11}$ the Court of Appeals in Rzeszow stated that the phrase "until the day that one leaves this state" contained in Article 13, point 10 of the u.s.u.s. should be explained (with regard to the representatives of the Catholic Church from the point of view of Canon Law) only as the situation wherein a person has forfeited the religious state or has been defrocked (by either a court verdict or administrative decree that declares the invalidity of ordination, the punishment of expulsion imposed in accordance with the codes of the law, respect of the Holy See). In this respect, the court considered the statement of the interested party inadequate. The court noted that, based on the justification, a different line of reasoning would lead to

10 Por. W. Sobczak, Ubezpieczenie spoteczne na wniosek zainteresowanego, PUS i G 1999, no. 3, pg.16. 
absurd situations wherein the insurance system's coverage would depend on the declaration.

In principle, optional insurance covers clergy during the periods indicated in the application for inclusion and exclusion from these insurances. In special cases, these insurance contracts cease ex lege. According to Article 14, paragraph 2, point 2 of the u.s.u.s., this goes into effect on the first day of the calendar month for which the premiums are due but have not been paid on time, unless the ZUS accepts the insured's application to agree to pay the premium after its due date. The application should indicate the circumstances justifying the assignment of a new date of payment.

Regardless of whether it is obligatory or optional, social insurance entails the obligation to pay contributions that are due on time. This argument was upheld by the Warsaw Court of Appeals on October 4, $2000^{12}$ in its ruling that the person who applies for voluntary medical insurance and expects benefits from the pension provider is obliged to pay the insurance premiums on time and in the appropriate amount.

Article 47, paragraph 1 of the u.s.u.s. states that contributions should be paid no later than 1 ) the $10^{\text {th }}$ day of the following month, in the case of a cleric who pays only for himself, 2 ) by the $5^{\text {th }}$ day of the following month, in the case of budgetary units, budgetary establishments, and ancillary enterprises, and 3 ) by the $15^{\text {th }}$ day of the following month, for other payers.

Article 14, paragraph 2, point 2 of the u.s.u.s. indicates that violating the deadline specified in Article 47, paragraph 1 of the u.s.u.s. results, in principle, in a given person's automatic exclusion from health insurance. The insured may, however, request and obtain consent to pay the premium after the deadline. If the pension provider agrees and the insured pays his contribution in the time period set by ZUS, then the social insurance will continue. If the pension provider does not grant consent, then the health insurance expires by virtue of the law. The provision stipulates that the pension provider agree to this change in "justifiable cases." The legislation does not explain this term, leaving the pension provider to assess the situation and determine whether the insured's justification of his failure to meet the payment deadline is reasonable. This reason should be objective. If the circumstances were due to the insured's deliberate fault, then they do not warrant restoring the due date. ${ }^{13}$ This does not mean, however, that the applicant

$12 \quad$ III Aua 1514/ 99, OSA 2001, nr 4, poz. 15.

13 See the decree issued by the Court of Appeals of Lublin on July 19, 2017, III AUa 1434/16, LEX nr 2333181. 
is completely at fault. ${ }^{14}$ Consent to pay the premiums on a different date than the one required by insurance regulations is completely justified in the event that the delay was not excessive and occurred, for example, due to illness.

On August 8, 2001, the Supreme Court ruled that in every case a subject's termination of voluntary social insurance coverage or reintroduction of voluntary social insurance requires that the person concerned submit a new application. However, once a voluntary insurance title does cease to exist by law, then payment for voluntary social insurance contributions does not ensure continued insurance coverage by the expired voluntary social insurance. The decision of the pension body to refuse to restore the deadline for paying voluntary social security contributions (currently, not agreeing to pay the premium after the deadline) is subject to appeal to the labor and social security courts. ${ }^{15}$ The Supreme Court of Gdansk also came to a similar decision on September 29, 2016. ${ }^{16}$ The court stated that the competence awarded to the pension body should be determined by verifiable and fair criteria. ZUS should disclose the reasons why it refused to agree to allow the individual to pay the premium after the deadline, and its decision is subject to substantive assessment by the court.

In light of the provision of the Act, health insurance ceases by law in the event of non-payment within the time period that the premium for the insurance policy is due. The same applies if the premium is not paid in full. The Supreme Court decision on April 18, 2012 confirms this conclusion. ${ }^{17}$ It states that the use of the term "premium due" is intentional because the adjective that refers to the contribution means that it is full premium and not just part of the premium. The premium due is that which should be paid. If the premium is not due

14 See the decree issued by the Court of Appeals of Lublin on October 27, 2016, III AUa 253/16,LEX nr 2157790; decree issued by the Court of Appeals of Lublin on May 31, 2017, III AUa 1298/16, LEX ne 2304349.

15 The decree issued by the Supreme Court on November 7, 2001, II UKN 577/ 00, OSNP 2003, nr 15, poz. 361; decree issued by the Court of Appeals of Gdansk on May 6, 2016, III AUa 2104/15,LEX nr 2106961; decree issued by the Court of Appeals of Gdansk on June 8, 2016, III AUa 148/16, LEX nr 2106943.

III AUa 684/16, LEX nr 2157829; the decision issued by the Court of Appeals of Lodz on November 3, 2000, III Aua 774/00, upholds that the literal and systemic interpretation of the provision of the second sentence of Article 14, paragraph 2, point 2 of the Act that was issued on October 13, 1998 regarding the social insurance system indicates that ZUS's position, which is expressed the matter of restoring the payment deadline for voluntary insurance contributions, is not subject to judicial review, OSA 2001, nr 2, poz. 5 . 
and, therefore, less than due, then the voluntary medical insurance ceases to exist under the law.

If the benefit was collected for part of a given month, then medical insurance ceases from the day following the last day for which the allowance provides coverage. The same applies if an individual receives remuneration for his inability to work as a result of illness or sequestration due to an infectious disease.

As a rule, contributions toward mandatory pension, disability, and accident insurance for clergy are financed in the following way: $20 \%$ of the premium is covered by the insured, and the remaining $80 \%$ is covered by the Church Fund. The latter pays insurance premiums for members of contemplative cloistered orders and missionaries while they are working in mission territory. The provisions stipulate that the Church Fund is obliged to pay $80 \%$ of the amount (which is the difference between the amount of the minimum wage and the income from work provided as an employee) toward mandatory retirement and pension insurance for clergy who provide spiritual service. Clergy who obtain voluntary insurance are obliged to pay their contributions toward it in full.

In general, minimum wage is used to calculate insurance payments. The amount may be increased at the insured's request. The clergy or diocesan and religious institutes should finance the premium from the base of the assessment in the part exceeding the value of the minimum remuneration (Article 18, paragraph 11 of the u.s.u.s.).

\section{Conclusion}

In the social insurance system, the religious state as a rule is an independent insurance title. In particular circumstances, it is necessary to be subject to pension and disability insurance under other titles as well. This applies to situations wherein the basis for social insurance contributions under an employment contract or the execution of a civil law contract is lower than the minimum remuneration. In the first case, however, coverage includes only the difference between the remuneration obtained and the minimum wage. This limitation, however, is irrelevant with regard to mandated contracts and contracts for the provision of services. Remuneration (due to contracts) that is lower than the minimum renumeration makes it necessary for the insured to pay premiums for both a civil law contract and for pastoral ministry.

Clergy who engage in business are mandatorily subject to social insurance as an economic entity, which is different from other kinds 
of non-agricultural activities. In effect, according to the general rule, a member of the clergy who is also an artist, for example, and is subject to the retirement and pension insurance for the role in which he enrolled earliest, can also change the insurance title.

Some officers of uniformed services have an opportunity to simultaneously collect insurance benefits and social provision. It is highly doubtful whether such regulations violate the constitutional principle of equality.

\section{UBEZPIECZENIA SPOŁECZNE DUCHOWNYCH W USTAWODAWSTWIE POLSKIM}

Przedmiotem rozważań są kwestie dotyczące podlegania ubezpieczeniom społecznym przez osoby duchowne. Omówiono sytuacje, w których duchowni są objęci tymi ubezpieczeniami w sposób obowiązkowy. Dotyczy to ubezpieczeń emerytalnego, rentowych oraz wypadkowego. Analizie poddano także przepisy regulujące dobrowolne ubezpieczenie chorobowe, zwracając w szczególności uwagę na konsekwencje wiążące się z nieopłaceniem należnej składki. W opracowaniu przedstawiono także konsekwencje wynikające ze zbiegu tytułów ubezpieczeniowych. W praktyce kwestie te budzą najwięcej wątpliwości.

Słowa kluczowe: duchowny, ubezpieczenia społeczne, składka na ubezpieczenia.

\section{Bibliography:}

1. Bińczycka-Majewska T., Zbieg tytutów ubezpieczenia emerytalnego i rentowego w nowym systemie ubezpieczeń społecznych, "Praca i Zabezpieczenie Społeczne" 2000, no. 12

2. Pędzierski A., Podstawa wymiaru sktadek na ubezpieczenia społeczne i ubezpieczenia zdrowotne, "Praca i Zabezpieczenie Społeczne" 1999, no. 9.

3. Pędzierski A., Zmiany przepisów z zakresu podlegania ubezpieczeniom społecznym i składek na ubezpieczenie społeczne oraz na Fundusz Pracy i Fundusz Gwarantowanych Świadczen Pracowniczych, "Praca i Zabezpieczenie Społeczne" 2000, no. 1.

4. W. Sobczak, Ubezpieczenie społeczne na wniosek zainteresowanego, "Przegląd Ubezpieczeń Społecznych i Gospodarczych" 1999, no. 3 